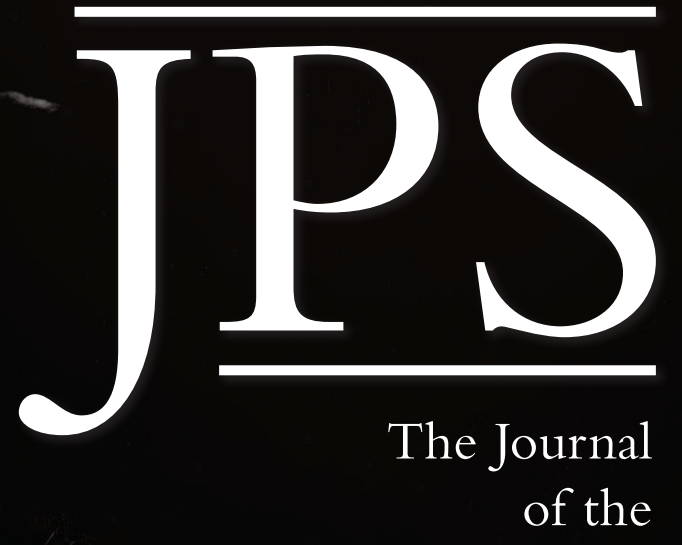

Polynesian Society

VOLUME 124 No.2 JUNE 2015

THE POLYNESIAN SOCIETY

18

,

$3:$

THE UNIVERSITY OF AUCKLAND

NEW ZEALAND 


\title{
PERSONHOOD AS HISTORY: MĀORI CONVERSION IN LIGHT OF THE POLYNESIAN ICONOCLASM
}

\author{
JEFFREY SISSONS \\ Victoria University, Wellington
}

Reflected light enhances both ethnographic and historical visibility. In this article I seek to illuminate processes of Māori conversion to Christianity in the late 1830 s and early 1840 s using as my comparative mirror an event that I have termed "The Polynesian Iconoclasm" (Sissons 2014). The Polynesian Iconoclasm was, I have argued, a complex regional event that occurred between 1815 and 1828 involving the peoples of the Society Islands, Austral Islands, Cook Islands and Hawaiian Islands. Beginning in Mo'orea, Tahiti's near neighbour, priests and high chiefs across the region destroyed or defiled their god-images and defied eating taboos by participating in feasts at which men and women, chiefs and commoners ate the same food together. Although they were reported by missionaries, the Europeans did not directly initiate the iconoclastic episodes and most were not witnessed by them. This regional event was also a seasonal one, with most of the destructive episodes taking place during the season when life was traditionally regenerated - the makahiki season in Hawai' $i$ or its equivalents elsewhere.

In conceptualising The Polynesian Iconoclasm as a single regional event I excluded from my comparative frame Māori conversions to Christianity; in New Zealand the process of rapid, mass conversion began in the late 1830s and was clearly not widely preceded by episodes in which god-images and temples were aggressively destroyed. I knew that in both Island Polynesia and New Zealand mass conversions took the form of a rapid burst or pulse, but I assumed that the ways in which the pulses were triggered and the subsequent unfolding of events were very different. However, a historical note written by a former Māori priest, Hamiora Tumutara Pio, has led me to reconsider the relationship between the two conversion events, that is, to rethink Māori conversion in light of the Polynesian Iconoclasm and, to a lesser extent, vice-versa.

Born, according to his own account, in 1814, the year that the Church Missionary Society began evangelising in New Zealand, Tumutara Pio belonged to a generation of young tohunga 'priests/shamans' whose training was interrupted by Christian conversion in the late 1830s and 1840s. After his baptism into the Catholic Church, at which time he took the name Hamiora (Samuel), he became a travelling catechist, one of a number of young, chiefly men who were largely responsible for the very rapid spread of Christianity 
south of the Bay of Islands in the 1840s (Mead 1981: 1-12). Among the fruits of this evangelisation in the Bay of Plenty, where Tumutara and his Ngāti Awa people lived, were 11 Catholic chapels constructed during the late 1830s and early 1840s (Belich 1996: 217-19, Thompson 1859: 313).

However, as colonial pressures, epidemics and fraudulent land dealings increased during the $1850 \mathrm{~s}$, erupting into the colonial wars of the $1860 \mathrm{~s}$ and 1870 s, Tumutara became disillusioned with Christianity, coming to regard it as a destructive, foreign religion. The only hope for Māori people, he wrote, was to return to their former gods and religious practices. His biographer, Hirini Mead, a latter day Ngāti Awa leader, described Tumutara as having "lived uncomfortably" between pre-Christian and Christian worlds and this was generally true, but by the 1880 s Tumutara had very clearly rejected his former Christian beliefs. The ethnographer, Elsdon Best, reported, for example, the following conversation:

Pio once remarked that a priest came to him and said, 'O Pio! Return to the Catholic faith'. But Pio answered: 'I have an ancestor of my own. You keep your ancestor and I will keep mine'. 'Who is your ancestor?' asked the other. 'Rangi [sky] is my ancestor, the origin of the Maori people. Your ancestor is money’. (Best 1925: 1032)

There is indeed a sense of discomfort and bitterness evident in the notes and commentaries that Tumutara sent to John White, author of Ancient History of the Maori (1897), and to the ethnographer Elsdon Best in the 1880s. These texts, for which Tumutara was paid, now fill more than 30 notebooks and comprise a valuable collection of historical narratives, proverbs, genealogies, ritual chants and personal commentaries. In some of his last commentaries written for Best in 1887, Tumutara drew a stark contrast between a lost world that had been animated by his ancestor-gods and a present world animated by money. The regeneration of Māori life required, he insisted, a rediscovery of Māori ancestry and a restoration of tapu 'ancestrally derived sacredness' so that the mauri 'life principle, life force' of his people could regain its former strength. Tumutara lamented the condition of his people's mauri but he did not entirely blame a European presence for this. Instead, he told Best: "The mauri (life principle) of the Maori has become polluted [noa], that is what is destroying the Maori people.... I say to you that the Maori is at fault: He has deserted his ancestral rites, customs and beliefs and now they [the ancestorgods] have turned on him and are destroying him" (Best 1904: 221).

The separation of people from the tapu of their ancestors had, Tumutara wrote, been deliberately produced through rites of pollution performed at the time of conversion to Christianity (Mead 1981: 25-26). Basing his account on Tumutara's text, Best wrote: 
... they proceeded to whakanoa or make themselves common or free from tapu that they might be able to accept the new religion. For the tapu was of the Maori gods and hence must be got rid of, or reduced, so to speak, before the new God was accepted. This was done, in most cases, by washing the head with water heated in a vessel in which food had been cooked.... It was enough to cause the whole horde of gods in the Maori pantheon to turn on the race and destroy it. The most sacred part of sacred man to be brought into contact with cooked food! (Best 1904: 221)

Below is Tumutara's original text, upon which Best's was based, followed by my translation:

Ka whanau au (i te tau) 1814. Ka rongo au ko te karakia Mihinare. Ka nui haere te matemate ki tenei motu. To mua mate, he iti nei. Nui rawa aka to te whakapono. Katahi ka tino motu te urupa nui o te hunga e whakapono ana, no te mea kua ruku te Mãori ki roto I te wai kohua, i te wai wera, no te mea ko tona mauri kua noa. Koia nei e patu nei te Mãori. (Mead 1981: 25-26)

I was born in the year 1814. I heard about the Missionary Church. A great number of epidemics came to this island. Earlier sickness was on a small scale. There was great desire for the Christian faith. But then many cemeteries appeared like many islands of fallen believers. This was because Māori believers had performed ritual ablutions using cooking water, hot water, it was because their sacred life force had been desecrated [become noa]. This is how the Māori was struck down.

When I first read this text, soon after completing The Polynesian Iconoclasm, it was as if the words had leapt off the page at me. Could Tumutara have been referring to a ritual event that paralleled the Polynesian Iconoclasm, I wondered? Could he, perhaps, have been describing a widespread process of personal transformation in New Zealand that preceded baptism and mass participation in Christian practices?

In the first part of this article I tentatively answer these questions in the affirmative, presenting and discussing documentary evidence for preconversion whakanoa rites in New Zealand. Furthermore, I argue that, like the destructive episodes of the Polynesian Iconoclasm, these whakanoa rites were improvisations upon ritual precedents and hence can also be understood, like those elsewhere in Polynesia, as forms of "rituopraxis"-improvised ritual acts intended to produce revolutionary change.

Whereas in the societies of the Polynesian Iconoclasm the rites were directed against both images and chiefly bodies, in New Zealand they were most commonly directed solely against the latter. In a concluding discussion I argue that a Deleuzian-inspired understanding of social life, one grounded 
in an ontology with which Tumutara would have felt a strong affinity, helps us to conceptualise the similarities and differences between the two conversion events. Developing an idea introduced in an earlier article in this journal (Sissons 2013), I propose that we view hapu and the more highly centralised Polynesian chiefdoms as "assemblages" consolidated around intense centres. Transformative ritual action upon these centres by priests (the mode of historical action that I term "rituopraxis") has the potential to produce revolutionary social change. In making this argument I also seek to build on the pioneering writings of Marshall Sahlins on the relationship between chiefly personhood and historical agency in Polynesia.

\section{TE WHAKANOA MĀORI: A MĀORI CONVERSION EVENT}

Māori interest in Christianity exploded in the late 1830s and early 1840s. In 1844, for example, the Anglican Missionary Register recorded an increase in church attendance from 2000 in 1840 to 35,000 in 1844. A year later, the chief protector of aborigines, George Clarke, estimated a total of 64,000 people of all denominations professing Christianity (Yates 2013: 127). While the accuracy of these figures is open to question (e.g., Belich 1996: 217-18), an astonishing rise in the number of people becoming baptised or preparing for Christian baptism is, I think, beyond dispute. In her forceful reply to Owens (1968), Judith Binney provided additional figures in support of this view and explicitly compared the eventual rapidity of Māori conversions to those of island Polynesia:

... in the history of the nineteenth century missions in the South Pacific there appears a common pattern. First, there is a long period in which the words of the missionaries seem to make little impact.... This period is followed by a relatively sudden breakthrough.... (Binney 1969: 143-44)

Binney proceeded to identify and discuss what she saw as the main causes of this "breakthrough", stressing missionary agency rather than the power of the missionaries' ideas as Owens had done. She considered that one of the principal reasons for the dramatic increase in Māori interest in Christianity was a change in the way missionaries engaged with Māori culture and society. The Mission, under the leadership of Henry Williams, shifted its emphasis from "civilisation" to "Christianisation", putting more emphasis on learning the Māori language than had been the case previously. Secondly, missionaries were increasingly called upon to mediate inter-tribal disputes in a climate in which there was a new desire for peace. Thirdly, missionaries deliberately sought to "undermine belief in certain aspects of Maori culture as a precondition of being accepted as a Christian" (Binney 1969: 151). Among these "aspects of Māori culture" were beliefs and practices associated with tapu. 
Binney rightly dismissed as exaggerated missionary claims, made in 1836, that their own efforts had caused practices of "tapuing" to become "nearly extinct" in the North. She did, however, credit the Mission with significant agency in relation to the changing significance of tapu and an associated undermining of chiefly authority:

It is to be expected that early converts would include chiefs.... And if, as Yate believed, serious inroads were being made on the efficacy of tapu, then those whose prestige, personal sanctity and political powers depended on tapu must seek an alternative or supplementary protective force to sustain their authority. (Binney 1969: 156)

In identifying a temporal parallel between Polynesian and Māori conversions and taking seriously the issue of chiefly tapu, Binney perceptively anticipated the argument that I am making here. The critical difference between us is that for her the chiefly search for a new "protective force" was in reaction to missionary "interference" whereas in my view Māori chiefs and priests, like those in Polynesia, actively polluted their own tapu in order to realise a new political and personal vision. Missionaries did not direct this practice in Polynesia - indeed there was no missionary presence in Hawai' $i$ at the time of the iconoclasm there in 1819 — and nor did they do so in New Zealand.

It is clear, as Binney noted, that by the late 1830s there was a widespread desire among Māori leaders for more peaceful relations among themselves following the unprecedented inter-tribal wars of the $1820 \mathrm{~s}$ and $1830 \mathrm{~s}$ (Troughton 2014). This fighting had caused massive social disruption as whole communities migrated to new lands or were forcefully displaced. In addition, of course, there had been many thousands of people killed (at least 20,000 in conservative estimates) and as many enslaved. Summing up the impact of the wars, Anderson has recently noted that if the comparatively low figure of 20,000 deaths is accepted it meant "about 700 additional deaths per year between 1810 and 1840 due to warfare. At a tribal or community level, it hardly needs emphasising, the impact would have been devastating" (Anderson et al. 2014: 186).

By 1840, inter-tribal fighting had begun to subside significantly and many communities were returning to their ancestral lands. It is surely no coincidence that precisely at this time Māori leaders began to explore more seriously than before the personal and political possibilities of Christianity. These possibilities, discussed and debated by chiefs and priests in the early 1840 s, would become powerfully realised some two decades later in the King Movement. Lindsay Head has convincingly argued that Christianity was fundamental to the political vision of Wiremu Tamihana, the driving force behind mahi kingi 'king work' 
(Head 2005: 65-71). But, as I have said, the conversion event was both political and personal and, if Tumitara Pio was correct, it coincided with radical transformations of chiefly and priestly personhood.

Let us now turn to a fuller consideration of Tumutara's claim that Christian conversion in New Zealand had been widely preceded by whakanoa rites and examine the evidence for it. We can assume, I think, that Tumutara based his historical claim upon his experiences as a Christian teacher who had spent most of his life in the eastern Bay of Plenty and Taupo (Mead 1981: 1-12). Given that most of the early work of conversion was carried out by catechists such as Tumutara (Yates 2013: 110), it is perhaps not surprising that the whakanoa rites to which he refers are not described in the missionary journals for his region. The only documentary evidence appears to be a suggestive comment by the CMS missionary Thomas Chapman. Chapman, who established a mission station at Rotorua in 1835, noted in November of that year that the people of Ohinemutu, under the leadership of the great war chief Korokai, had become "believers", having "done with their native karakia [rite]". There is a suggestion by Chapman that when Korokai told him of his people's new status he had also claimed to have become noa. Chapman was dismissive of this possibility, suggesting that Korokai had instead become "doubly tapu":

Our principal old chief, Korokai, remarked after service that they had now done with their native karakia (praying) and were become believers - poor old man! It is more than likely that he is doubly tapu' $d$ at this time in consequence of some 'rite' or other. (Chapman 1830-1845: 29 November 1835)

But if there is only this scant, ambiguous documentary evidence in support of Tumutara's claim for the Bay of Plenty/Rotorua region, his own written account together with others from Northland, Waikato and Wanganui suggest that there was indeed a wide geographic spread of pre-conversion whakanoa rites across the North Island during the decade 1835-1845. It is to these latter accounts that I now turn, beginning in Northland, as did the missionaries, and moving south.

The Weslyan missionary James Buller lived for three years in Hokianga from 1836 to 1839 . During this period he baptised the influential Waima chief, Mohi (Moses) Tawhai, together with a large group of 116 people, probably most of his hapu. Buller noted the difficulty that the chief had experienced in transitioning from polygyny to monogamy (1878: 35), but he did not record the more significant change to his chiefly personhood - the removal of his tapu. Fortunately, however, a description of this latter transformation was collected by Tumutara's correspondent, John White. In his 1861 lectures, "Maori Customs and Superstitions", White said of Mohi Tawhai: 
Doubting the power of his gods, he resolved to test it; and knowing that it was not lawful for cooked food to be near his head and that he must not sit within a cooking house or even enter into it, he notwithstanding bade one of his slaves take a pot and cook food in it; then filling the pot with water he washed his head with it and sitting down he waited the result. (White 1885: 164-65)

White added that, no harm having come to him, Mohi Tawahai decided to become Christian. White interpreted this episode as testing of the power of atua 'god', but it was equally an ending of the relationship with his atua and the power that it conferred through the pollution of both his body and the body of his atua.

In addition to this anecdote, White provides a second, more detailed account of an act of self-defilement that appears to have occurred in Northland at about the same time. This whakanoa rite was performed by a tohunga who was said to be still alive at the time of the 1861 lectures. Here, it is clearer that that the tohunga, who would take the Christian name Zaccheus, was not merely testing his atua but that he was polluting his body in order to become noa before his baptism. Intending to become Christian, Zaccheus summoned three people to his settlement and "... having had a quantity of kumara [sweet potato] cooked, and put into three baskets, he bade them place these upon the most hallowed part of his person - the shoulders and head - while the three ate from them" (White 1885: 164). White provides no identifying information about the three assistants but it is very likely that one or more of them were ruahine, old women who were expert in removing tapu.

The use of cooked food, particularly kumara and fern-root, was common to many whakanoa rites, particularly those associated with birth, warfare and death (Smith 1974: 9-20). Cooking made food (including human victims) noa, draining it of its life-giving connection with the gods and, as Smith notes, "the eating of cooked food completed the process" (1974: 28). The use of cooking water by Mohi Tawhai may not have had a direct precedent in other whakanoa rites but as an improvised prelude to baptism it would have been seen as a particularly effective way of bringing the extreme noa of cooked food into polluting contact with the most tapu part of the chief's body-his hair.

The use of fern-root in a tua rite to remove the tapu of birth from a child was recorded by Shortland, a fluent Māori speaker and scholar. During this rite a ruahine touched the child's body with cooked food in a way similar to that of the ruahine in the Zaccheus example above:

[She] took the child in her arms, waved over it the fernroot which had been cooked in her fire, then touched the different parts of the child's body with it. She was then said to eat this fernroot, but she actually spat on it and threw it 
on the sacred place [where the shrine was located]. The child was then free from tapu. (Shortland 1882: 42)

After battles, ruahine were called upon to remove the tapu of the war god, $\mathrm{Tu}$, from warriors by eating a kumara roasted by a tohunga on his ritual fire (Best 1897: 49). They were also employed after people had finished cleaning and reburying the bones of their deceased relatives to remove the tapu from their hands:

A fire would be specifically kindled, at which a small portion of food would be roasted, and this food was applied to the hands and then eaten by the female member of the family who acted as a ruahine in ceremonial performances. Such a woman is sometimes the oldest female of a family and she takes part in most tapu removing rites. (Best 1924: 261)

The old women who assisted Zaccheus were, therefore, probably his elderly relatives who acted as his ruahine in a rite that was an improvised variation of those described by Shortland and Best above.

We now travel south from Northland to Waikato where whakanoa performances were recorded by three Anglican missionaries, James Hamlin, Robert Maunsell and Benjamin Ashwell, during the period 1836 to 1842.

In mid-1836, about a year after he and James Stack had established a mission station on the Waipa River at Mangapouri, Hamlin recorded that a gathering of chiefs had participated in a whakanoa ceremony. The principal chiefs on this occasion were named Rewetahi and Mangai, the latter taking the Christian name of Ihaia (Isaiah). We learn that these two men called a large meeting to discuss Christianity and subsequently invited a ruahine to perform a whakanoa ceremony:

The two men before mentioned and their tribe were engaged during the week in making themselves noa or free and the ceremony was as follows. It commenced by the priestess [ruahine] cutting off some of the hair of the head of each of the chiefs and throwing it into the [cooking] fire which [the hair] was so sacred in the native determination that it is nothing more or less than death to a chief to basen [sic] a bit of their hair. The next thing they did was to cook some potatoes in the native oven [its stones heated by the above fire] and when they were dressed some of them were put by the priestess upon the head of each of the persons made noa and then eaten, which takes away the sacredness of the head.... After this the priestess repeated some words, at the same time biting the hair of each person's head, or at least of the chiefs.... The system of merely taking off the sacredness is different from this. (Hamlin 1826-1837: 21 June 1836) 
This ceremony appears to have creatively combined two distinct whakanoa processes: the placing of cooked food on the head and the "cooking" and "eating" of the chiefs" hair. Together they were said to have constituted a rite more powerful than those for "merely taking off sacredness".

Hair was the most tapu part of a chief's body and was, as Salmond has noted (1989: 74), "conceived of as a pathway for the gods to pass into the body". Haircutting was, therefore, "tapu to a degree that varied with the intensity of an individual's communication with the gods". Human hair had an equivalent significance elsewhere in Polynesia, where it was sometimes incorporated into god-images and headdresses (Sissons 2014: 122). By throwing chiefly hair into a cooking fire and biting the hair on the chiefs' heads, the ruahine was not only polluting the chiefs' tapu but was also decisively cutting off communication between the chiefs and their atua.

The parallel with the destruction of Polynesian images, also a means a communication with atua, is clear. At Mo'orea, for example, at the beginning of the iconoclasm there in 1815, wooden altars from marae 'sacred spaces' were used to fuel cooking fires for feasts at which men and women, chiefs and commoners, ate together (Sissons 2014: 42). In Rarotonga, eight years later, a local priest signalled the beginning of an island-wide iconoclasm by cutting up and throwing his god-image into a fire. Bananas were then baked in the ashes and eaten (Sissons 2014: 74).

In our second Waikato example only the hair-cooking component of the first rite was described. The report is by Benjamin Ashwell who drew upon a lengthy conversation with the Waikato chief, William Tawaitai, following a Sunday service in 1842. Tawaitai, who had recently been baptised into the Weslyan Church, told Ashwell that he had only become Christian after a protracted struggle: "As a decisive step, he cut off his hair, which was sacred, and threw it into the fire which was cooking food for his slaves. The chiefs of Waikato, hearing of this profane act, brought a fight [raiding party] to kill his slaves.... (Missionary Register 1844: 203-4).

The party of angry Waikato chiefs remained in Tawaitai's settlement for several weeks debating his actions but were unable persuade him to abandon his plan to join the Christians. They left without killing his slaves. Tawaitai was a renowned and highly respected Waikato leader - he was involved, for example, in brokering peace between the tribes of Rotorua and Tauranga the following year - and so it is quite possible that his actions encouraged others to follow his example (Ballara 1976: 499).

The third Waikato whakanoa episode for which I have documentary evidence also included burning, but in this instance it was chiefly clothing rather than chiefly hair that was thrown into the flames. The account is by 
Robert Maunsell who, in November 1839, was stationed at Maraetai, Port Waikato. The leader of the Ngāti Tipa community in which Maunsell was living was Kukutai, a warrior of great mana; the episode in question concerned his grandson, Ngataru, also a man of great mana and described by Maunsell as an ariki 'highly sacred, paramount chief'.

Ngataru was dying of consumption and had moved to the mission settlement in the hope that it would aid his recovery. This move and the ariki's expressed wish to be baptised drew determined opposition from his grandfather. Maunsell wrote that "Kukutai had sent word that he would not consent to his - Ngatara's - becoming noa (common) while he retained his garments"- two blankets and a woven outer cape (Church Missionary Record 1840: 282). The difficulty that Kukutai had raised was that, while Ngataru could undergo a whakanoa rite to remove the tapu from his body, his clothing would retain its tapu and so could no longer be worn by Ngataru in a state of noa. Ngataru suggested to his wife that a tohunga be employed to remove the tapu from his garments, but she pointed out that it would not remove the awe with which they were viewed by people and hence they would still retain a semblance of tapu-ness. In the end it was agreed therefore that the best course of action would be to burn the garments. Maunsell wrote (Church Missionary Record 1840: 284): “The next morning, Lord's Day, I was called out before six o'clock to witness the smoke of the burning garments. That same day Ngataru, his wife and his two children were admitted into the fold of Christ before a crowded and overflowing congregation." Ngataru took the Christian name of Edward and his wife was baptised as Mary.

There would, of course, have been no point in burning Ngataru's clothing had his body not been previously rendered noa. We can assume, therefore, that the rites for the latter had been performed before Maunsell was "called out" and so he would not have witnessed them. Kukutai must have understood the event as a whakanoa ceremony because when he arrived later that day he wept over his grandson who had lost his tapu connection with his gods, and hence with himself (Church Missionary Record 1840: 284).

We next travel further south to Wanganui where during a visit in December 1839, a month after Ngataru's baptism, the CMS missionary Henry Williams learned of a performance of a rite very similar to that of Mohi Tawhai in Hokianga. Williams wrote that the rite was termed "kokiro" a word that William Williams' (1971) dictionary translates as 'set free from tapu'. It was, in other words, a whakanoa rite. Here is Williams' account:

Heard much of a baptism which had been introduced by this man, Neira, which I condemned in toto. His ceremony appears to be washing the head, which has always been considered sacred by the New Zealanders, in warm water out of an iron pot, the person, at the same time confessing sins, vainly 
imaging that thereby his sins will be pardoned, a washing away of sin and a release of tapu very much according to native custom. (Williams 1827-1840: 12 December 1839)

"This man Neira" was, however, far from vain or misguided. He was, in fact, a Waikato chief of great mana who had become the region's greatest evangelist. Baptised into the Wesleyan Church under the name William Naylor (Wiremu Neera), he had been preaching to almost all the hapu of south Taranaki and had taught classes for two years preparing candidates for Christian baptism (Yates 2013: 111). It is highly improbable that Neera regarded his kokiro rite as replacing baptism into the Christian Church or that it was intended to remove Christian sins. It is more likely that it was a necessary part of the preparation for baptism, removing connections with atua. Bronwyn Elsmore was surely right to conclude that Williams "totally misinterpreted Neera's ministrations" (Elsmore 1989: 128).

Some six years after Williams visited Wanganui a further probable whakanoa rite was recorded there. Tragically, as in the Waikato, it again involved the conversion of a dying ariki. The account is by the CMS missionary and fluent Māori speaker, Richard Taylor, who moved to Putiki in 1843. In September 1845, Taylor recorded that when he visited the dying ariki, Turoa, he was surprised by the latter's "declaration that he had renounced heathenism and from this time he should remove the tapu from his body and karakia to God" (Taylor, 4 September 1845, emphasis added).

Taylor did not record the performance of the whakanoa rite for Turoa but the ariki attended church for the first time three days after Taylor's visit. At his service he was baptised with the name Kingi Hori (King George). Taylor continued:

Immediately the service was over and he had openly renounced the faith of his ancestors in which he had obstinately lived during the whole period of a long life, his people cried and set up a loud wail. This I fancy is done because his tapu as an 'Ariki' or chief priest is broken.... This lamentation only takes place when principal chiefs are baptised. I have noticed it on two or three previous occasions. (Taylor, 7 September 1845)

It is unlikely that those who wept believed that Taylor's baptism alone had "broken" the ariki's tapu. Rather, a prior whakanoa rite, not witnessed by Taylor, must have been performed to "remove the tapu from his body". Sadly, Hori Kingi lived for only three days after his baptism.

There are, again, clear parallels here with events of the Polynesian Iconoclasm. In Aitutaki, in 1822, for example, the rejection of his gods by the ariki and his refusal to participate in annual rites for the re-establishment of hierarchy prompted women to weep and cut themselves, spreading the 
resulting blood over their bodies. In neighbouring Rarotonga, women responded in an identical way when the ariki burned his marae a year later (Sissons 2014: 71, 74). In all of these episodes from New Zealand and elsewhere in Polynesia it was as if the ariki had died, which indeed was true in that he had broken his links with the sources of his and his people's life.

Our final example is from Patea, a little north of Wanganui, where, perhaps, the nearest equivalent to episodes of the Polynesian Iconoclasm may have occurred. Writing in 1899, the Rev. T. G. Hammond recorded that on several occasions within the memory of his then living informants, whakanoa rites were performed on god-images (Hammond 1899: 89-92). These rites are not dated, but they probably occurred after 1830 and before the people became Christian, that is around the time of conversions to Christianity. The hap $\bar{u}$ of Wanganui and the surrounding region appear to have been distinctive in New Zealand in their use of carved and bound god-images (whakapakoko rakau) for communication with atua (Barrow 1959). Richard Taylor, who was given 13 such images that had, at the time of conversion, been concealed in clefts and hollow trees wrote: "The natives of Wanganui had many gods, and likewise images of them, the principal ones were Maru, Kahukura, Reua [Rehua] Korongomai [Rongomai]. In the Northern part of the Island I never met with any of these images" (Taylor 1840-1844: 360).

While these images had been concealed around the time of conversion in the early 1840s, Hammond's informants witnessed - possibly at about the same time - images being "cooked" in fires.

If it was found that any particular atua or image was doing injury to the people this would necessitate the destruction which would be accomplished by cooking some food, and putting the atua in the fire while the food was being cooked. Each member of the tribe would partake of a portion of the food, the ariki having repeated the necessary incantations. (Hammond 1899: 92)

The parallel between this rite and the way that god-images were "cooked" and "eaten" in the societies of the Polynesian Iconoclasm is striking.

If, as Tumutara claimed in his historical commentary, the performances of whakanoa rites before Christian conversion were widely practiced within Māori society, then the above examples from Northland, Waikato and Wanganui probably represent the tip of an iceberg. Many more such episodes must have gone unrecorded by missionaries as they struggled to understand the whirlwind of confusing events happening around their newly established southern stations. Māori evangelists, such as Tumutara in the Bay of Plenty and Taupo and Wiremu Neera in Wanganui, are more likely to have witnessed these rites than the Europeans whose presence would have been 
regarded as intrusive and whose criticism, like that of Williams, would have been unwelcome. Indeed, Tumutara, a former tohunga, may have himself undergone and/or performed the rites that he would only describe in later life.

\section{INTENSE CENTRES AND PRIESTLY HISTORY}

In all but one of our documented examples the whakanoa rites were performed on highly tapu individuals - chiefs, tohunga and ariki. Wiremu Neera may have included men of lesser mana, but he probably would not have extended his performances to women or slaves who were already noa. In general, then, the whakanoa event appears to have been focussed on the pollution of highly tapu, chiefly bodies (images possibly featuring only in and around Patea). In concluding this article I address the following question: if these ritual acts of pollution triggered or impelled mass conversion in New Zealand in a way that was analogous to the Polynesian Iconoclasm, how might we account for this?

In an earlier article (Sissons 2013) I proposed that in order to understand the radical changes that Māori hapu underwent during the second half of the 19th century, it is useful to view them, in Deleuzian terms, as "assemblages" (Deleuze and Guatarri 1987). As an assemblage, a kin-group such as the Māori hapū includes people and ancestors, some of whom are present in the landscape as springs, rivers, mountains, flora and fauna, while others are rendered present in objects such as carved meeting houses. Assemblages become "territorialised" or consolidated around "intense centres", which hold them together as effectively as relations of hierarchical control. In the case of hapu, I have demonstrated how these assemblages were reterritorialised around a succession of tapu ritual centres during the 19th century - shrines (pre-1840), churches (1840-1860) and meeting houses (from about 1875). I also suggested, but did not develop the idea, that certain chiefs and priests were themselves intense tapu centres of their hapu $\bar{u}$ and were closely identified with their shrines, churches and meeting houses (Sissons 2013: 378, 384). I would now like to take this idea further and argue that if, as tapu centres, chiefs, ariki and tohunga consolidated hapu and hapu alliances around their personhood, their pollution was a pre-requisite, hence "trigger", for reterritorialising Christianising kin-groups around churches as new sacred centres.

The understanding of social life as consolidated around intense centres is as much a general Polynesian one as it is Deleuzian. Across 19th century Polynesia, variations in the degree of hierarchy corresponded to variations in the levels of intensity of the tapu centres. In the Society Islands, Hawai' $i$ and Mangaia, where hierarchy and the intensity of tapu were most extreme, the personhood of high chiefs was founded on their socially totalising embodiment of the gods, 'Oro, Kū and Rongo respectively. In Rarotonga and Aitutaki the tapu personhood of ariki was associated with district gods. 
In all cases the intense tapu of chieftainship was distributed throughout the societies in the form of images kept within the god-houses of temples. Iconoclasms in these places were focussed, therefore, on both the pollution of the bodies of the kings, chiefs and priests through collective feasts and the destruction or defilement of their images and temples bringing about the transformation of whole societies.

In a brilliant comparison between annual Makahiki rites in Hawai' $i$ and annual kumara rites in New Zealand, Sahlins (1985a) has shown these to be structural transformations of each other. In the former, Kū (embodied as an intensely tapu high chief) defeats Lono (in the form of an image), while in the latter, Tū (represented by humanity in general) triumphs over Rongo (embodied as kumara that is harvested and eaten). Correspondingly, the pollution of the intensely tapu centre in Hawai' $\mathrm{i}(\mathrm{K} \bar{u})$ and the destruction of his temples and images initiated a transformation of the whole society, while in New Zealand, the pollution of less tapu high chiefs (who embodied local atua while sharing in a generalised embodiment of Tū) initiated the

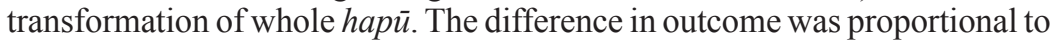
the difference in tapu intensity - hence consolidating power - of the centres but the process was essentially the same.

Sahlins has coined the term "heroic history" to describe a Polynesian mode of social change centred upon chiefs. History was, he proposed, embodied in the divine personhood of chiefs: "Embodying and making history, ruling chiefs thus practice socially the capacities that they are given cosmologically" (Sahlins 2000: 324-25). Sahlins further argued that, in enacting their cosmological capacities and putting their cosmological schemes into practice, Polynesian chiefs were engaging in a distinctive form of historical agency that he termed "mythopraxis" (Sahlins 1985b: 54-72). I have suggested, however, that in many contexts we might substitute the terms "priestly history" and "rituopraxis" for "heroic history" and "mythopraxis" (Sissons 2014: 7). It was the primary responsibility of priests to reproduce society or, in the case of rituopraxis, to bring about radical change through ritual actions upon tapu centres. Irrespective of whether this praxis was aimed at images - wrapping, feeding or parading them — or whether it was aimed at the bodies of the tapu chiefs themselves, in all cases historical change was equated with transformations of divine personhood. If chiefs embodied cosmological order, priestly actions upon their bodies produced history. Such was the case for the Polynesian Iconoclasm and also, I suggest, for the Māori whakanoa event. And it was not only the tapu of others that was of concern to priests who initiated iconoclasms and tohunga in New Zealand-the tapu nature of their own personhood also needed to be addressed. In New Zealand, as we have seen, at least one tohunga organised his own bodily pollution. 
In the immediate aftermath of iconoclasms in the Society Islands, Austral Islands and Southern Cook Islands the people of these places embarked upon projects of chapel construction. More than one hundred small chapels were built in Tahiti and Mo'orea in 1816, for example, and in Rarotonga Christians gathered together to begin work on a massive church intended to be 600 feet in length (Sissons 2014: 85, 94). In New Zealand, as in Tahiti, whakanoa rites were accompanied by the construction of many small churches in Christian settlements across the country, these becoming the focal points for a reformation of kin-group identity. By the 1860 s, however, as disillusionment with Christianity became widespread in New Zealand, most of these churches had been abandoned and left to decay. In the Bay of Plenty, Waikato and elsewhere a new form of whare karakia, the carved meeting house, replaced the chapel as a re-established centre of intense tapu (Sissons 2010, 2013).

One such early meeting house was Te-Whai-a-te-Motu 'The Pursuit through the Island', built at Ruatāhuna to commemorate the pursuit of Te Kooti Arikirangi by government forces through Te Urewera. At the opening of this house in February 1891 its tapu nature was a matter of great public concern. While most people wanted the building to remain intensely tapu, Te Kooti, who attended the opening, opposed this view and with 20 tohunga removed the tapu from the meeting house (Binney 1995: 471). At least one of Elsdon Best's informants - and possibly Tumutara Pio himself - believed that this whakanoa rite, like those that accompanied conversion, had had tragic consequences: "When an epidemic swept off their children by scores during the latter part of 1897, that was punishment for the tribe having taken the tapu off the big carved house, Te Whai-a-te-Motu at Mata-atua [Ruataahuna]" (Best 1898: 235).

Deleuzian and Polynesian ontologies are in agreement that tapu is not simply one half of a binary relationship: tapu-noa. Rather, tapu is an immanent plane of intensive differences - it infuses and animates the entire Māori universe - out of which social difference is actualised through priestly practice. As Deleuze put it, more generally, in his brilliant book, Difference and Repetition:

Difference is not diversity. Diversity is given [or actual] but difference is that by which the given is given [i.e., virtual]. Every phenomenon refers to an inequality by which it is conditioned.... Everything which happens and everything which appears is correlated with orders of differences: differences of level, temperature, pressure, tension, potential, differences of intensity. (Deleuze 1994: 293) 
Tumutara Pio would probably have agreed, adding "differences of tapu" to the differences of intensity listed by Deleuze.

For Deleuze, life was about repeating well, that is, repeating as an on-going, creative emergence or "becoming" driven by intensive difference. For Deleuze, as it was for Tumutara, intensive differences produce life, are life (Deleuze 1994: 23). And so when Tumutara wrote that the pollution of people's tapu was responsible for Māori decline he was not only pointing us towards an alternative historical understanding, but also towards an alternative ontology in which personhood, grounded in intensive difference, gains and loses historical force. Tumutara would have termed this force "mauri".

\section{REFERENCES}

Anderson, A., J. Binney and A. Harris, 2014. Tangata Whenua: An Illustrated History. Wellington: Bridget Williams Books.

Ballara, A., 1976. The role of warfare in Maori society in the early contact period. Journal of the Polynesian Society 84 (4): 487-506.

Barrow, T., 1959. Maori Godsticks Collected by the Rev. Richard Taylor. Dominion Museum Records in Ethnology 1(5). Wellington.

Belich, J., 1996. Making Peoples: A History of the New Zealanders from Polynesian Settlement to the End of the Nineteenth Century. Auckland: The Penguin Press.

Best, E., 1897. Te Rehu o Tainui: The evolution of a Maori atua. Journal of the Polynesian Society 6 (2): 41-66.

1898. Omens and superstitious beliefs of the Maori, Part II. Journal of the Polynesian Society 7 (4): 233-43.

1904. Maori medical lore. Journal of the Polynesian Society 13 (4): 213-37.

-1924. The Maori. Volume 1. Wellington: The Polynesian Society. 1925 Tuhoe: The Children of the Mist. Wellington: Government Printer.

Binney, J., 1969. Christianity and the Maoris to 1840: A comment. The New Zealand Journal of History 3: 143-65.

-1995. Redemption Songs: A Life of Te Kooti Arikirangi Te Turuki. Wellington: Bridget Williams Books.

Buller, Rev. J., 1878. Forty Years in New Zealand. London: Hodder and Stoughton.

Chapman, Rev. Thomas, Letters and Journal v. 1, 1830-1845. (Typescript), Alexander Turnbull Library, Wellington.

Church Missionary Record, 1840. Volume 11. London: Church Missionary Society.

Deleuze, G., 1994. Difference and Repetition. London: Bloomsbury.

Deleuze, G. and F. Guatarri, 1987. A Thousand Plateaus: Capitalism and Schizophrenia.

Translated by B. Massumi. Minneapolis: University of Minnesota Press.

Elsmore, B., 1989. Mana from Heaven: A Century of Maori Prophets in New Zealand. Tauranga: Moana Press.

Hamlin, Rev. James, MS. Journal 1826-1837. Alexander Turnbull Library, Wellington. Hammond, T., 1899. Atua Maori. Journal of the Polynesian Society 8 (2): 89-92. 
Head, L., 2005. Wiremu Tamihana and the mana of Christianity. In J. Stenhouse (ed.), Christianity, Modernity and Culture: New Perspectives on New Zealand History, Adelaide: ATF Press, pp. 58-86.

Mead, H. (ed.), 1981. Nga Taonga Tuku iho a Ngati Awa: Ko nga Tuhituhi a Hamiora Pio, Te Teko (1885-1887). Department of Maori Studies, Victoria University of Wellington.

Missionary Register, 1844. Volume 32. London: Church Missionary Society.

Owens, J., 1968. Christianity and the Maoris to 1840. The New Zealand Journal of History 2: 18-40.

Sahlins, Marshall, 1985a. Hierarchy and humanity in Polynesia. In A. Hooper and J. Huntsman (eds), Transformations of Polynesian Culture. Auckland: The Polynesian Society, pp. 195-217. 1985b. Islands of History. Chicago: Chicago University Press. 2000. Culture in Practice. Chicago: Chicago University Press.

Salmond, Anne, 1989. Tribal words, tribal worlds: The translatability of tapu and mana. In M. Marshall and J. Caughey (eds), Culture, Kin and Cognition in Oceania: Essays in Honour of Ward H. Goodenough. Washington: American Anthropological Association, pp. 55-78.

Shortland Edward, 1882. Maori Religion and Mythology. London: Longmans, Green and Co.

Sissons, Jeffrey, 2010. Building a house society: The reorganisation of Maori communities around meeting houses. Journal of the Royal Anthropological Institute (n.s) 16: 372-89.

2013. Reterritorialising kinship: The Māori hapuu. Journal of the Polynesian Society 122 (4): 373-91.

2014. The Polynesian Iconoclasm: Religious Revolution and the Seasonality of Power. Oxford: Berghann Books.

Smith, Jean, 1974. Tapu Removal in Maori Religion. Memoir 40. Wellington: The Polynesian Society.

Taylor, Rev. Richard, Journal 1840-1844. (Typescript), Alexander Turnbull Library, Wellington.

Thompson, A., 1859. Story of New Zealand: Past and Present, Savage and Civilized. London: John Murray.

Troughton, G., 2014. Missionaries, historians and the peace tradition. In A. Davidson et. al. (eds), Te Rongopai 1814, “Takoto te Pai!'”: Bicentenary Reflections on Christian Beginnings and Developments in Aotearoa New Zealand. Auckland: Anglican Church, pp. 228-45.

White, John, 1885. Maori Customs and Superstitions [Lectures from 1861]. Electronic source: Early New Zealand Books: University of Auckland. 1887. Ancient History of the Maori. 6 volumes. Wellington: Government Printer.

Williams, Rev. Henry. Journals. Typescript. Alexander Turnbull Library, Wellington.

Williams, William, 1971. A Dictionary of the Maori Language. 7th edition. Wellington: Government Printer.

Yates, T., 2013. The Conversion of the Maori: Years of Religious and Social Change, 1814-1842. Michigan: William B Eerdmans Publishing Company. 


\begin{abstract}
In The Polynesian Iconoclasm: Religious Revolution and the Seasonality of Power (Berghann Books 2014) I described the desecration of god-images and temples during the period 1825-1828. I excluded Māori society from the analysis because there images were not as central to religious life and mass conversions to Christianity occurred in the $1840 \mathrm{~s}$. In this article I propose that the later mass conversion in event in New Zealand shared significant features with the Polynesian Iconoclasm. In both instances priests directed their ritual practice towards intense tapu centres, polluting chiefly bodies and triggering radical collective change.
\end{abstract}

Keywords: Mass conversion, ritual pollution, chiefly personhood, New Zealand Māori, Polynesian Iconoclasm

\title{
CITATION AND AUTHOR CONTACT DETAILS
}

Sissons, ${ }^{1}$ Jeffrey, 2015. Personhood as History: Māori Conversion in Light of the Polynesian Iconoclasm. Journal of the Polynesian Society 124 (2): 129-146.

DOI: http://dx.doi.org/10.15286/jps.124.2.129-146

${ }^{1}$ Corresponding author: School of Social and Cultural Studies, Victoria University of Wellington, PO Box 600, Wellington 6140, New Zealand.

E-mail: jeff.sissons@vuw.ac.nz 